\title{
EXPERIMENTAL STUDY: DETERMINATION OF CONCRETE REINFORCEMENT CONDITIONS
}

\section{ESTUDO EXPERIMENTAL: DETERMINAÇÃO DAS CONDIÇÕES DE REFORÇO DE BETÃO}

\author{
Khalid Abdel Naser ABDEL RAHIM ${ }^{1}$
}

${ }^{1}$ University of Coimbra, Department of Civil Engineering, Coimbra, Portugal, khalid.ar@outlook.com

\author{
A R T I C L E I N F O \\ Article history: \\ Received 2019-04-21 \\ Accepted 2019-06-27 \\ Available online 2019-06-28

\section{palavras-chave \\ Condições de reforço \\ Profundidade da capa \\ Resistividade de concreto \\ $1 / 2$ mapeamento celular \\ Conteúdo de cloreto}

\section{keywords} \\ Reinforcement conditions \\ Cover depth \\ Concrete resistivity \\ $1 / 2$ Cell mapping \\ Chloride content
}

\begin{abstract}
A B S T R A C T
This paper is about the determination of concrete reinforcement conditions. The concrete reinforcement condition testing is a process by which different test are carried out such as cover depth, concrete resistivity, 1/2 - cell mapping and chloride content, to determine how each test shows the effects of corrosion in the reinforced concrete. Four different types of tests were conducted on two different reinforced concrete cubes to investigate the embedded bar conditions. The tests were cover depth, concrete resistivity, $1 / 2$ cell mapping and chloride content tests. The experimental testing was carried out in the concrete laboratory at the University of Dundee.
\end{abstract}

R E S U M O

Este artigo é sobre a determinação das condições de reforço de concreto. O teste de condições de reforço de concreto é um processo pelo qual diferentes testes são realizados, como profundidade de cobertura, resistividade de concreto, mapeamento de $1 / 2$ célula e teor de cloreto, para determinar como cada teste mostra os efeitos da corrosão no concreto armado. Quatro tipos diferentes de testes foram conduzidos em dois cubos diferentes de concreto armado para investigar as condições da barra incorporada. Os testes foram testes de profundidade de cobertura, resistividade do concreto, $1 / 2$ mapeamento celular e teor de cloretos. O teste experimental foi realizado no laboratório de concreto da Universidade de Dundee. 


\section{INTRODUCTION}

\subsection{Overview}

The BS 1881: Part 124: 1988. Methods for analysis of hardened concrete, is set to determine cement type and content, aggregate grading and content, sulphate content, alkali content and most importantly the chloride content. This includes determination of chloride content calculation, method and procedure.

The concrete reinforcement condition testing in the structures lab consisted of four tests cover depth, concrete resistivity, $1 / 2$ - cell mapping and chloride content. The testing has been carried out on two concrete specimens with same w/c ratio and volume, but with different cover depth, resistivity, $1 / 2$ cell potential and chloride content.

In the first section of this manuscript, the main causes of corrosion in reinforced concrete will be theoretically argued. In addition, the theory behind methods and what is done for each test carried out in the lab will be presented. Moreover, the merits and limitations of each test will be identified. The results obtained in the lab for each test will be presented and discussed. Additionally, the percentage of chloride by rate of cement was calculated for the two concrete specimens and was compared to spot which cube contains chloride. Finally, the identification to which of the two reinforced concrete specimens has more resistivity of corrosion and which one has more potential of corrosion will be discussed according to the testing results.

\subsection{Main aims of the experimental study}

The main objectives of the experimental testing were:

- Achieve a better understanding of concrete reinforcement condition.

- Obtain a greater in-depth knowledge of concrete reinforcement condition testing procedures and tests carried out in experimental testing.

- Be able to carry out cover depth, concrete resistivity, $1 / 2$ cell mapping and chloride content tests.

- Become familiar with the causes of corrosion in reinforced concrete.

- Be able to define merits and limitations of each reinforcement condition test.

- Finding out which of the two reinforced concrete specimens has more percentage of chloride by weight of cement and which one has more potential for corrosion.

\section{MAIN CAUSES OF REINFORCEMENT CORROSION IN CONCRETE}

The reinforcement corrosion in concrete can be identified as the appearance of rust on steel surface after collapse of the passive layer Broomfield (2007). The breakage of the passive layer occurs due to electrical potential difference in reinforcement of concrete.

The main causes of reinforcement corrosion in concrete are chloride, carbonation attacks and the presence of cracks in concrete due to different factors which will be discussed further in this section. Additionally, water and oxygen plays an important role in the occurrence of corrosion if they present in the cathode. These factors decrease the alkalinity.

\subsection{Chloride attack}

The chloride attacks can be generally described as the contact of chloride ions with the surface of reinforcement and existence of water and oxygen. The reaction of corrosion starts when the chloride ions penetrate the natural oxide film on the surface of steel. Moreover, the contact of chloride with steel surface must reach a threshold value in order for corrosion to take place. The threshold chloride value is the amount of chloride needed to attain corrosion Bertolini (2004). According to Gibson (1987) "the accepted value for the corrosion threshold is 0.20 percent total chloride by weight of cement". This percentage is the minimum sum of chloride ions by weight of cement in order for corrosion to start occurring, taking in to account the type of cement used for concrete. Gibson (1987).

The occurrence of chloride attack depends on two important aspects. The first aspect is the concrete quality, for example, type of cement, w/c ratio and moisture content. The second aspect is the environmental conditions, which consists of factors such as chloride concentration, temperature, speed of wind and variation in humidity. In addition, the chloride induced corrosion maybe influenced on other factors such as, the bar size of reinforcement, and depth of cover and geometry of section Jackson (1980).

The sea water can increase the risk of chloride attack to structure which is next to the sea level. Basically, the sea water contains salt with a percentage of chloride. Also it is known that the climate is humid at the sea side. The humidity contains water, which makes the concrete wet and causes a growth in the pore size of the concrete. Thus, the percentage of chloride which exists in the salt can penetrate the concrete through the extended pores and lead to corrosion in the reinforcement.

The amount of chlorides which exists in concrete is the most vital hazard, since it can lead to additional diffusion into depth of concrete and distortion of the passive film enclosing the steel. Jackson (1980).

\subsection{Carbonation attack}

Initially, the carbonation attack begins on the outer surface of the concrete and travels steadily to the internal parts and this result in a decrease in the $\mathrm{pH}$ level from a standard value of $\mathrm{pH} 13$ or 14 to a value of $\mathrm{pH}$ 9, due to the reaction of carbon dioxide and calcium carbonate from atmosphere and cement paste Bertolini (2004). This reaction creates calcium carbonate, which destroys the protective oxide layer and leads to corrosion of steel bar Halliday (2010). Furthermore, the corrosion due carbonation attack is manipulated by environmental factors such as, concentration of carbon dioxide in the atmosphere, temperature and humidity. Additionally, the permeability and alkalinity of concrete for instance can be considered as other factors. Accordingly, the increase of humidity to more than 75 per cent increases the rate of corrosion. Jackson (1980).

\subsection{Water, oxygen and climate}

In humidity conditions the percentage of water in the air is higher than that in dry conditions. Therefore, the water in atmosphere due to humidity makes the concrete wet. As the concrete becomes wet, this increases the size of pores in the concrete and allows different ions or elements, such as, chloride, carbon, oxygen to move easily through the concrete and reach the reinforcement. Once the ions penetrate the concrete and 
reach the reinforcement, they react with water to form a chemical reaction as shown in figure 1 . This chemical reaction leads to corrosion. In addition, the presence of cracks due to poor concrete in terms of quality allows the free movement of ions in concrete reach the reinforcement and cause corrosion. On the other hand, in dry atmosphere the concrete will be dry, solid and there will be no existence of water. This means that chloride, carbon, oxygen ions unable to diffuse into concrete, thus, there will be no chemical reaction to form corrosion.

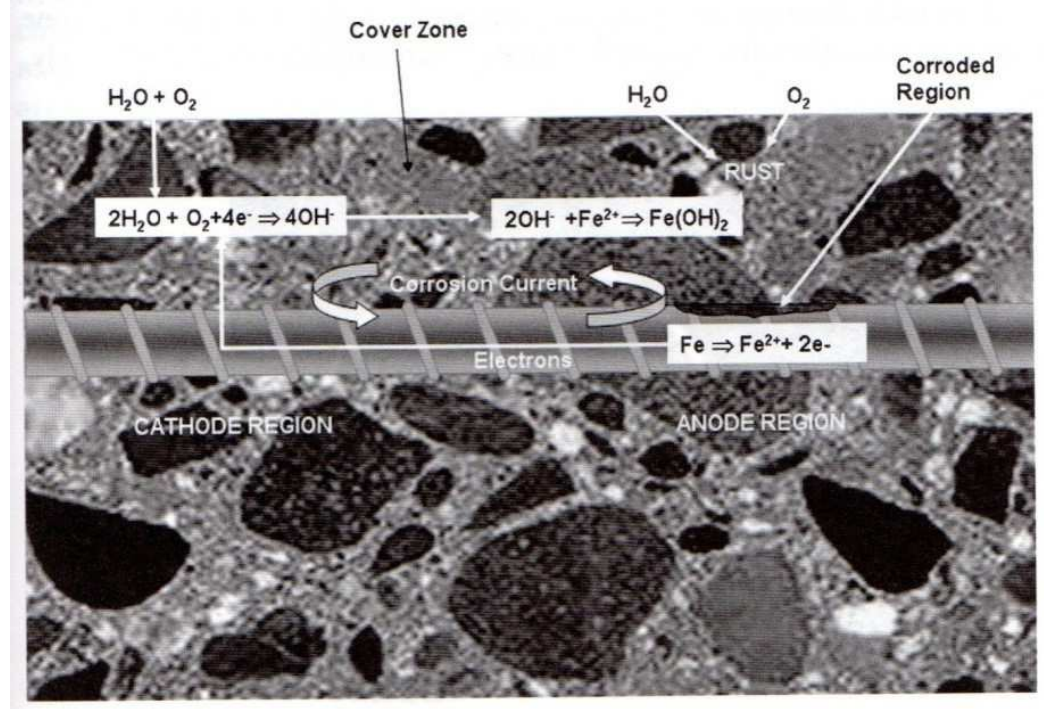

Figure 1 - Shows the reaction of corrosion in the reinforcement of concrete. MG Associates a Division of CET safehouse Ltd. (2010) Available online at http://www.concrete-testing.com/halfce1.jpg

\section{TESTING METHOD'S AND EQUIPMENT}

\subsection{Cover depth}

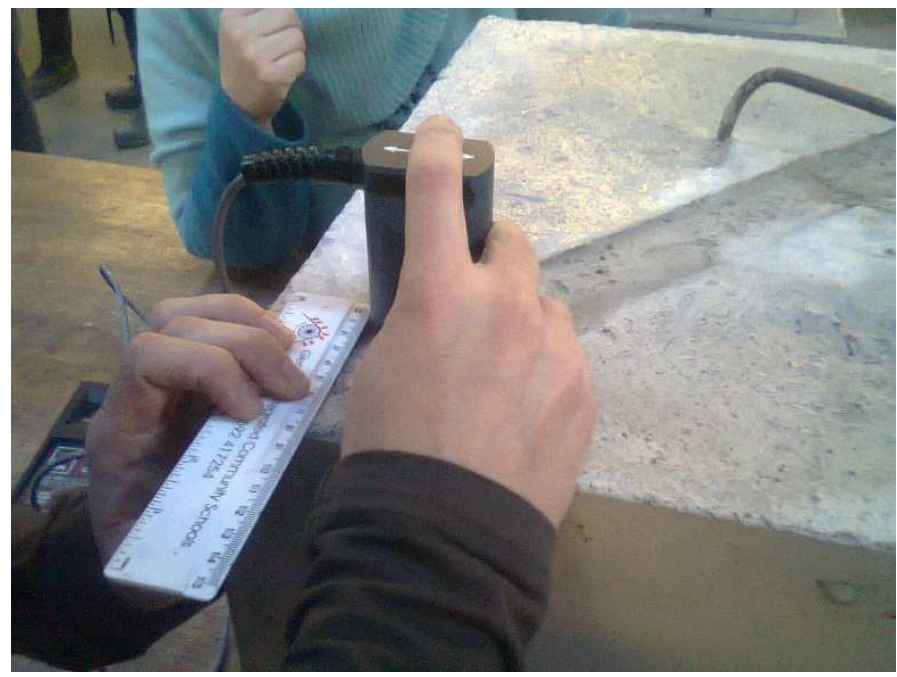

Figure 2 - Shows haw the measurement of cover depth test was carried out.

The cover depth test is indirect method of determining the corrosion of reinforcement in concrete. The generator coil sends electromagnetic fields (magnetic flux) through the concrete when placed on top of the concrete surface. The steel reinforcement will then influence the magnetic field current which travel in the concrete and causes a non-linear relation with the cover depth and the diameter of bar. Thus, the nonlinear relation is converter to numerical readings which appears on the moving coil meter. Bungey et al., (2006)

The test was carried out in accordance to BS 1881: Part 204 - Testing concrete and recommendations on the use of electromagnetic cover meters (AMD 6201). Initially, the existence of batteries in cover meter has been checked before starting the test. Then the cover meter was switched on by pressing the on/off button. Afterwards, the cover meter was adjusted by pressing the CAL button and voltage value was checked. The next step was placing the generator coil in contact with the concrete surface as shown in figure 2 . The first contact point was at the corner of the concrete when the generator coil was moved gradually within the concrete surface. The generator coil was kept moving until the cover meter starts to make noises. These noises indicate the presence of reinforcement. Then the generator coil is kept genteelly moving until hearing an increase of variance in noise. Subsequently, the reinforcement depth reading on the cover meter was recorded. After that the generator coil was held in place and the distance from concrete edge to the center of generator coil was measured using a ruler. The process of measuring the distance from the center of generator coil to concrete edge is shown in figure 2 . The above procedure has been carried out on top and side surfaces of concrete for cube 1 and just on the top surface for cube 2, Bergan et al. (1971).

\subsection{Concrete resistivity}

The concrete resistivity test is indirect method of determining the corrosion of reinforcement in concrete. In accordance to figure 3 , the four steel rods transfer electrical fields through the concrete when positioned on the concrete surface. This leads to an indication of the potential difference of the cover region with high risk of corrosion, Ayllon and Kelly (1972). The electrical fields are then reflected back to the earth resistance meter and it is converted to a numerical value which can be recorded in kilo ohms. The concrete resistivity is affected by different factors such as, moisture content, w/c ratio, cement type and humidity. Additionally, the presence of chloride and carbon ions either increases or decreases the conductivity (BS 
1881-201: 1986 Testing concrete). The test was carried out with respect to BS 1881: Part 201: 1986 - guide to the use of nondestructive methods of test for hardened concrete. Firstly, the earth resistance meter is turned on, AC adaptor was connected and a piece of wet sponge is placed on concrete surface. The wet sponge acts as a connector between steel rods and concrete surface. After that, the steel rod which is connected with the earth resistance meter via wires has been placed on the wet sponge. The next step was recording the resistivity value in $\mathrm{k} \Omega$ from the earth resistance meter. These procedures were carried out on four different surfaces of the concrete cube and there average was taken.

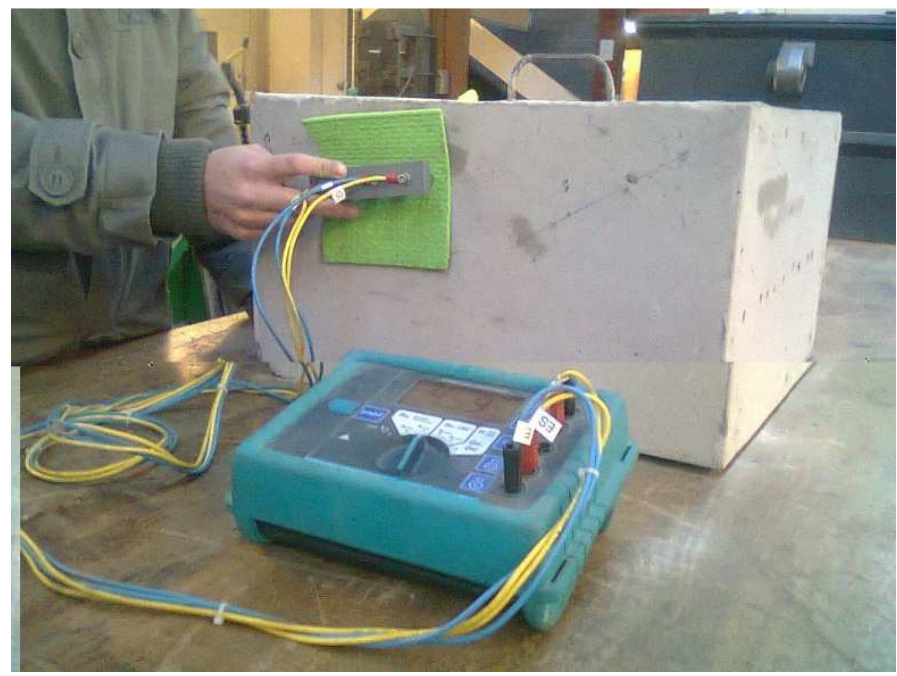

Figure 3 - Shows the procedures used for the concrete resistivity test.

\section{$3.31 \frac{1}{2}$ - Cell mapping}

The $1 / 2$ - cell mapping test is indirect method of determining the corrosion of reinforcement in concrete. The $1 / 2$ cell mapping provides an iso-potential contour map, which shows the corroded zones in the specimen. The silver/silver electrode transfers electro-chemical fields through the concrete surface. The wet sponge between the concrete surface and silver/silver electrode is necessary to maintain good transfers of electro-chemical fields to concrete. The electrode potential of reinforcement provides information of the corroded regions in the reinforcement.

The test was carried out with respect to the American standard ASTM C867 - Measuring and interpreting reference electrode potentials or reinforced concrete. Firstly, the two volt D.C. Scale which is connected to both the concrete and silver/silver electrode, has been switched on. After that a wet sponge was placed on the concrete surface to insure good contact between the concrete surface and the silver/silver electrode and to get better electrical connection. Then the silver/silver electrode was positioned on the wet sponge and readings were recorded from the two volt D.C. scale. Finally, the readings were converted from copper/copper to silver/silver by subtracting $100 \mu \mathrm{V}$ from each of the value obtained. These procedures was carried out at eight different positions for cube 1 and four different positions for cube 2 on the top surface of concrete cube. Figure 4 shows the procedures of this test.

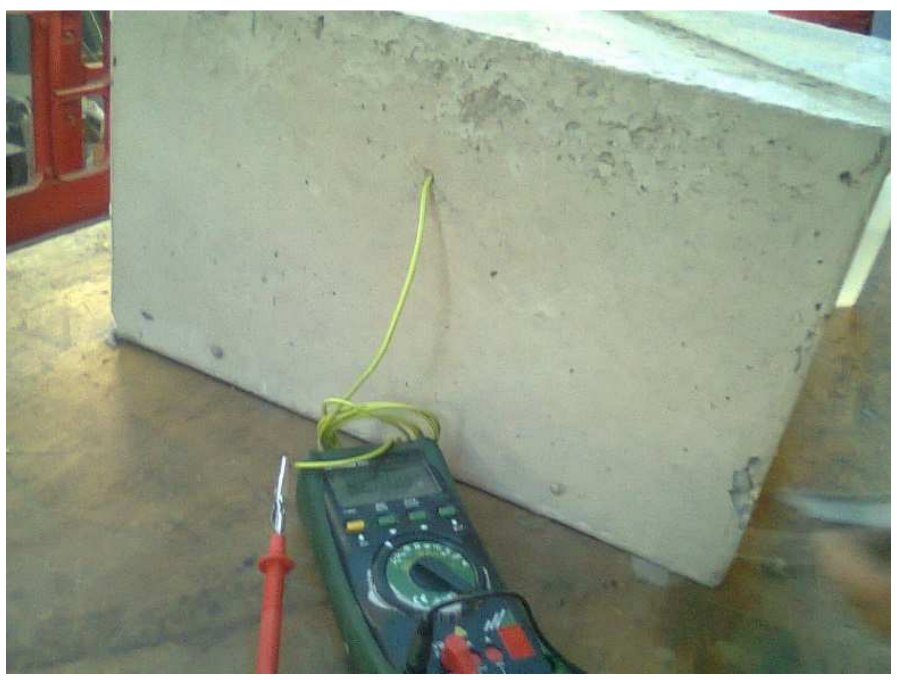

Figure 4 - 1/2 - cell mapping test.

\subsection{Chloride content}

The chloride content test is a direct method of determining the corrosion of reinforcement in concrete. With respect to figures 5 and 6 , the nitric acid solution and sodium carbonate when added to the concrete sample taken from concrete specimen, causes a chemical reaction. The chemical reaction in the mixture indicates the concrete alkalinity.

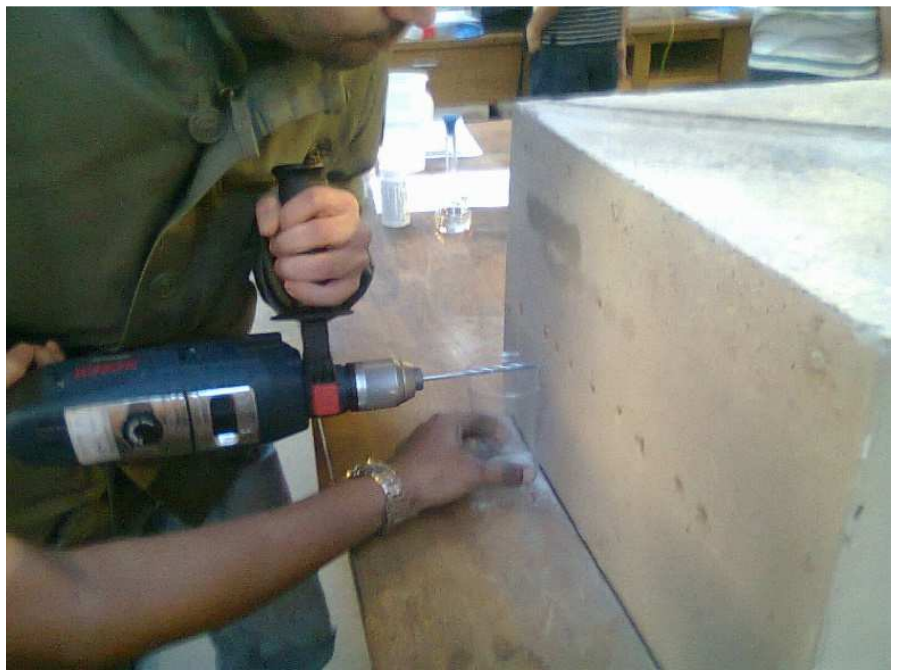

Figure 5 - Shows the concrete sample taken for chloride content testing.

The test was carried out with respect to the BS 1881: Part 124: 1988 Methods for analysis of hardened concrete. Firstly, a dry concrete sample was drilled out from the concrete specimen approximately 5 grams. The drilling in concrete cube was up to 25 millimeters. After that a 50 millimeters of 1 molar nitric acid solution was slowly added to the concrete sample. Then the mixture was stirred using a stirring rod for about two minutes. Subsequently, 5 grams of sodium carbonate was gradually inserted to the mixture. The sodium carbonate has been added gradually in order to prevent effervescence in the mixture. The next step was to again stir the mixture for another 2 minute until the sodium carbonate is totally dissolved in mixture. Afterwards the mixture has been left for 2 minutes to allow settlement. The mixture was then poured in to a dry funnel with a filter paper fitted inside it and the remains of the filtered mixture were taken in a container. Then a chloride titrator strip was inserted in the filtered mixture and kept for 5 minutes until the strip color 
changes to blue. Once the strip color becomes blue, the strip was taken out of the filtrate and was compared with a calibrated table provided on the chloride titrator strip tin to find the ppm in milligrams per liter. Finally, the percentage of chloride by rate of cement has been calculated using the below equation (1).

$$
\text { Croc }=\left(\frac{p p m}{1000}\right) \times 7
$$

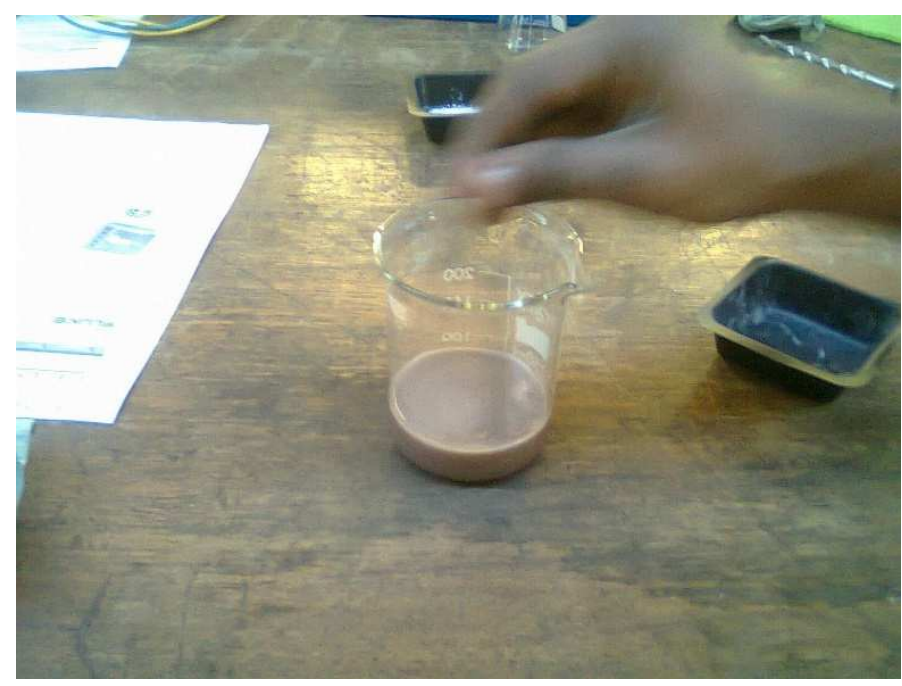

Figure 6 - Shows the mixture of concrete sample, sodium carbonate and nitric acid.

\section{MERITS AND LIMITATIONS OF EACH TEST}

\subsection{Cover depth}

The main usage of cover depth test is to measure the depth of reinforcement in concrete and diameter of bar. The cover depth is directed by managing the transfer of chloride ions, providing protection of steel against any chemical attacks and works as a fire resistance. In addition, the test gives an idea of which parts of the concrete is under corrosion, due to low cover depth, checks if the cover depth satisfies the design conditions and provide information of the position of steel under the concrete surface. This test have many merits, such as, it is direct, simple in testing, fast in operation and cheap. Additionally, the test does not cause any damage in concrete. On the other hand, the test requires good calibration and can only penetrate up to $300 \mathrm{~mm}$ in depth. Also, the verticality and horizontally of reinforcement can lead to issues in obtaining reliable readings. Finally, the reinforcement type in terms of steel and iron bearing aggregates can manipulate the magnetic field of the cover meter and give deceptive data with errors. Broomfield (2007).

\subsection{Concrete resistivity}

The concrete resistivity test is set to illustrate the resistivity of concrete against chloride penetration, rate of corrosion and the amount of water diffusion and determines the fall of voltage flanked by internal electrodes. Bertolini (2004). Moreover, it provides suggestion of the moisture amount in pores. The merits of this test are that it is quick to perform, easy in operation, does not cause damage in concrete and it is considered to be useful methods of testing if compared with other measurements, to check if the concrete is poor in terms of quality and to assists in recognizing other problems arise in concrete such as corrosion. Conversely, the limitations of test are that it does not provide a final prediction of the corrosion rate of concrete reinforcement. Moreover, the cost of test can vary from moderate to high. Additionally, the measurements obtained can only be used with other measurements from other tests in sequence to get sufficient predictions. Finally, the test can give errors and deceptive reading if not positioned at right angles when carrying out the measurements (Broomfield, 2007).

\section{$4.31 / 2$ - Cell mapping}

The $1 / 2$ - cell mapping test is associated with finding corrosion potential and risks. Also, it is used for examining the corrosion rate and condition of reinforcement in concrete. The advantages of $1 / 2$ - cell mapping test are that it is a straightforward and very helpful, non-destructive method of recognizes the risk of corrosion in different rebar regions with negative zones using an iso-potential contour map. Alternatively, the limitations of $1 / 2$ - cell mapping test is that it can vary from moderated to high in terms of cost. The test can give unclear readings with errors at the surface of concrete due to the effect of the cover depth, concrete resistivity and actual potential of corrosion. Also, this method of testing cannot find a precise corrosion rates and degree of reinforcement, Bertolini (2004).

\subsection{Chloride content}

This test is mostly used to find the existing amount of chloride in concrete and whether this amount is enough to cause corrosion. In addition, the test gives clarification of the coefficient of diffusion to forecast the partial ingress rate. Furthermore, it identifies haw the chloride existed in concrete, for instance, during the casting of concrete or due to later diffusion Broomfield (2007). The advantages of chloride content test are that it is low in price, easy in operation, quick test and gives accurate prediction of chloride content Gibson (1987). On the other hand, the limitations of chloride content test are that it produces a minor damage in the concrete surface after drilling out the testing sample (Neville, 1996).

\section{RESULTS AND DISCUSSION}

\subsection{Cover depth}

The results demonstrate cover depth in millimeters for two concrete specimens with same w/c ratio. Cube 1 had two bars and the position of these bars is presented in table 1 . The position of bar 1 at end 1 was $48 \mathrm{~mm}$ from the edge of concrete and $68 \mathrm{~mm}$ in depth. In addition, the situation of bar 1 at end 2 was $51 \mathrm{~mm}$ from the concrete edge and $82 \mathrm{~mm}$ in depth. Moreover, the place of bar 2 at end 1 was $83 \mathrm{~mm}$ from the edge of concrete and 64 in depth. The location of bar 2 at end 2 was $67 \mathrm{~mm}$ from the concrete edge and the depth of reinforcement was $84 \mathrm{~mm}$. On the other hand, cube 2 also had 2 bars and the positions of the two bars are presented in table 1 . For cube 2 the position of bar 1 at end 1 was $53 \mathrm{~mm}$ from the concrete edge and $60 \mathrm{~mm}$ in depth. In addition, the site of bar 1 at end 2 was $60 \mathrm{~mm}$ from the concrete edge and $75 \mathrm{~mm}$ in depth. Moreover, the location of bar 2 at end 1 was $80 \mathrm{~mm}$ from concrete edge and $80 \mathrm{~mm}$ in depth. Furthermore, the position of bar 2 at end 2 was $52 \mathrm{~mm}$ from the concrete edge and $100 \mathrm{~mm}$ in depth. Generally, the results illustrates that the reinforcement of specimen 1 is higher in depth than the bars in cube 2. Additionally, the cover depth results showed difference in value at end 1 and end 2 . This 
means that both reinforcements in cube 1 and 2 is bent and is not straight in position inside the concrete cubes.

It is known that as the cover depth is higher, the less potential for corrosion to take place in the reinforcement of concrete and the opposite is true. This may be clarified by saying that the cover depth acts a defender for the bars against chloride or carbon ions or other element such as water or oxygen that can cause problems in the reinforcement like corrosion. Subsequently, if the cover depth is low, the less time taken for chloride, carbon, water and oxygen ions to penetrate the concrete and reach reinforcement. Therefore, the higher the cover depth is the more protection of bars and less potential against corrosion. It has been concluded that the reinforcement at cube 1 is deeper than these in cube 2 , thus, specimen 1 has more potential against corrosion than specimen 2 .

Table 1 - Results of cover depth test for reinforced concrete cube 1 and 2. (Abdel Rahim, 2019)

\begin{tabular}{|c|c|c|c|c|c|}
\hline Surface No. & End No. & $\begin{array}{c}\text { Cube } 1 \\
\text { X1 Distance / } \\
\text { mm }\end{array}$ & $\begin{array}{c}\text { Cube 1 } \\
\text { Y1 Distance / } \\
\text { mm }\end{array}$ & $\begin{array}{c}\text { Cube } 2 \\
\text { X1 Distance / } \\
\text { mm }\end{array}$ & $\begin{array}{c}\text { Cube } 2 \\
\text { Y1 Distance / } \\
\text { mm }\end{array}$ \\
\hline \multirow[t]{2}{*}{ Surface 1 Top } & 1 & 48 & 68 & 53 & 60 \\
\hline & & 83 & 64 & 80 & 80 \\
\hline \multirow[t]{2}{*}{ Surface 1 Top } & 2 & 51 & 82 & 60 & 75 \\
\hline & & 67 & 84 & 52 & 100 \\
\hline \multirow[t]{2}{*}{ Surface 2 Side } & 1 & 75 & 72 & - & - \\
\hline & & 70 & 70 & - & - \\
\hline \multirow[t]{2}{*}{ Surface 2 Side } & 2 & 83 & 66 & - & - \\
\hline & & 43 & 69 & - & - \\
\hline
\end{tabular}

\subsection{Concrete resistivity}

Table 2 illustrate the results obtained in structures lab for concrete resistivity test for two concrete specimens of same w/c ratio. The resistivity value for surface $1,2,3$ and 4 was 3.78 , $3.7,3.63$ and $4.59 \mathrm{k} \Omega$ respectively. Consequently, the average concrete resistivity value for cube 1 was $3.925 \mathrm{k} \Omega$. The resistivity values for cube 2 with readings of $0.853,0.971,1.589$ and 1.590 with respect to surface $1,2,3$ and 4 . Therefore, the average resistivity for cube 2 was $1.251 \mathrm{k} \Omega$. According to Broomfield (2007) if the concrete resistivity value is less than 5 $\mathrm{k} \Omega$ then the rate of corrosion is very high. This indicates that both cube 1 and 2 are under a very high rate of corrosion, since the resistivity value for both of them is under $5 \mathrm{k} \Omega$. It is believed that the higher the concrete resistivity value the less potential for corrosion to occur, Dai and Ueda (2011), Dawei et al. (2012) and Zhang et al. (2012). On the other hand, the average resistivity value for cube 1 was higher than cube 2 . Therefore, the risk of corrosion in cube 2 is higher than cube 1 . In other words, with respect to the resistivity results obtained, it has been observed that cube 1 has more resistivity against corrosion than cube 2 .

Table 2 - Results of concrete resistivity test for reinforced concrete cube 1 and 2.

\begin{tabular}{lll} 
& \multicolumn{2}{c}{ Resistivity / k $\mathbf{~}$} \\
Surface No. & Cube 1 & Cube 2 \\
\hline $\mathbf{1}$ & $\mathbf{3 . 7 8}$ & 0.853 \\
$\mathbf{2}$ & 3.7 & $\mathbf{0 . 9 7 1}$ \\
$\mathbf{3}$ & 3.63 & 1.589 \\
$\mathbf{4}$ & 4.59 & 1.590 \\
Average & 3.925 & 1.251 \\
\hline
\end{tabular}

\section{$5.31 / 2$ Cell mapping}

Tables 3 illustrate the results obtained in structures lab for $1 / 2$ - cell mapping test for two concrete specimens of same w/c ratio. The $1 / 2$ - cell potential results at eight different positions for cube 1 were $80.14,90.3,103.5,103.1,101.5,78.3$, 29.6 and $73.4 \mu \mathrm{V}$. Thus, the average $1 / 2$ - cell potential was 82.48 $\mu \mathrm{V}$. The value of $82.48 \mu \mathrm{V}$ shows less than $5 \%$ of corrosion, since it is positive in value and more than $-200 \mu \mathrm{V}$. Furthermore, table 3 demonstrates the results of the $1 / 2$ - cell potential for cube 2 at four different places at top surface of the concrete with values of $-303,-352,-327,-296 \mu \mathrm{V}$ and the average of these was $-319.5 \mu \mathrm{V}$. According to table 4 , the value of $-319.5 \mu \mathrm{V}$ which is between the range of -350 and $-250 \mu \mathrm{V}$ clarifies a $50 \%$ of corrosion in the reinforcement. It is known that a higher $1 / 2$ - cell potential value reveals better corrosion resistivity. Therefore, cube 1 has less potential to corrosion than cube 2 , since it has positive and higher $1 / 2$ - cell potential than cube 2 .

\begin{tabular}{|c|c|c|c|c|}
\hline \multicolumn{5}{|c|}{$1 / 2$ cell-mapping / $\mu \mathrm{V}$} \\
\hline Point No. & $\begin{array}{l}\text { Cube } 1 \\
* \text { C/C } \\
\text { Chloride } \\
\text { Cell }\end{array}$ & $\begin{array}{l}\text { Cube } 1 \\
* * \text { S/S } \\
\text { Chloride } \\
\text { Cell }\end{array}$ & $\begin{array}{l}\text { Cube } 2 \\
\text { C/C } \\
1 / 2 \text { Cell }\end{array}$ & $\begin{array}{l}\text { Cube 2 } \\
\text { S/S } \\
1 / 2 \text { Cell }\end{array}$ \\
\hline 1 & 180.14 & 80.14 & -203 & -303 \\
\hline 2 & 190.20 & 90.30 & -252 & -352 \\
\hline 3 & 203.50 & 103.5 & -227 & -327 \\
\hline 4 & 203.10 & 103.1 & -196 & -296 \\
\hline 5 & 201.50 & 101.5 & & \\
\hline 6 & 178.30 & 78.3 & & \\
\hline 7 & 129.60 & 29.6 & & \\
\hline 8 & 173.40 & 73.4 & & \\
\hline Average & & 82.48 & & -320 \\
\hline
\end{tabular}

Note: *C/C (Copper/Copper) and $* *$ S/S (Silver/Silver)

Table 4 - The table shows the relationship between average $1 / 2$ - cell mapping and the percentage of corrosion according to Halliday (2010).

\begin{tabular}{|ll}
\hline \multicolumn{1}{|c|}{$\mathbf{1} / 2$ Cell-mapping $/ \boldsymbol{\mu V}$ vs. $\%$ of Corrosion } \\
\hline Average $1 / 2$ cell reading $(\boldsymbol{\mu V})$ & \% of corrosion \\
\hline Less than $\mathbf{- 3 5 0}$ & 95 \\
Between $\mathbf{- 3 5 0}$ and $\mathbf{- 2 5 0}$ & 50 \\
More than -200 & 5 \\
\hline
\end{tabular}

\subsection{Chloride content}

Tables 5 present the results obtained in structures lab for chloride content test for two concrete specimens of same w/c 
ratio. The quantab value for cube 1 was 1 with a $27 \mathrm{mg} / \mathrm{l}$ for ppm and the percentage of chloride by rate of cement was $0.189 \%$. On the other hand, the quantab value for cube 2 was higher than that of cube 1 with a value of 1.2 and $33 \mathrm{mg} / \mathrm{l}$ intended for $\mathrm{ppm}$ value. In addition, the percentage of chloride by rate of cement was $0.231 \%$. It is known that as the percentage of chloride by rate of cement increases the less potential against corrosion, thus, higher risk of corrosion. Gibson (1987) has stated that "... the corrosion threshold starts to appear if the percentage of chloride by weight of cement is more than $0.20 \%$ ". Since the percentage of chloride by rate of cement for cube 2 is higher than $0.20 \%$ with a $0.231 \%$ of chloride it is more likely to have corrosion than cube 1 which had $0.189 \%$ of chloride.

Table 5 - Results of chloride content test for RC cube $1 \& 2$.

\begin{tabular}{llll} 
Cube No. & $\begin{array}{l}\text { Quantad } \\
\text { Units }\end{array}$ & $\begin{array}{l}\mathbf{1} / \mathbf{2} \text { cell-mapping / } \mathbf{\mu V} \\
\mathbf{m g} / \mathbf{l}\end{array}$ & $\begin{array}{l}\text { Percentage of } \\
\text { chloride by } \\
\text { rate of cement } \\
/ \%\end{array}$ \\
\hline $\mathbf{1}$ & 1 & 27 & 0.189 \\
$\mathbf{2}$ & 1.2 & 33 & 0.231 \\
\hline
\end{tabular}

\subsection{Comparing results}

The results of all concrete reinforcement tests that were carried out has been summarized and presented in table 6 . The results of cover depth and concrete resistivity tests illustrated a consistent relationship between depth of reinforcement, resistivity of concrete and penetration of chloride, carbon, water and oxygen. This specifies that as the cover depth is bigger, the resistivity of concrete is better and less risk of ions penetration, therefore better concrete quality in terms of corrosion resistivity. On the other hand, the results for $1 / 2$ - cell mapping and chloride content showed a uniform relation with each other. The relation was that an increase in $1 / 2$ - cell potential with a decrease in chloride content means a good concrete in terms of more potential against corrosion. Generally speaking, the concrete resistivity and potential against corrosion is mainly affected by cover depth and chloride content.

Table 6 - Results of chloride content test for RC cube $1 \& 2$.

\begin{tabular}{|c|c|c|c|c|}
\hline \multicolumn{5}{|c|}{$1 / 2$ cell-mapping / $\mu \mathrm{V}$} \\
\hline Test & $\begin{array}{l}\text { Cube } 1 \\
\text { X1 } \\
\text { Distance } \\
\text { / mm }\end{array}$ & $\begin{array}{l}\text { Cube } 1 \\
\text { Y1 } \\
\text { Distance } \\
\text { / mm }\end{array}$ & $\begin{array}{l}\text { Cube } 2 \\
\text { X1 } \\
\text { Distance } \\
\text { / mm }\end{array}$ & $\begin{array}{l}\text { Cube } 2 \\
\text { Y1 } \\
\text { Distance } \\
\text { / mm }\end{array}$ \\
\hline Cover & 48 & 68 & 53 & 60 \\
\hline Depth & 83 & 64 & 80 & 80 \\
\hline Test & 51 & 82 & 60 & 75 \\
\hline$/ \mathrm{mm}$ & 67 & 84 & 52 & 100 \\
\hline $\begin{array}{l}\text { Concrete } \\
\text { Resistivity }\end{array}$ & & & & \\
\hline Test / k $\Omega$ & 3.925 & & 1.251 & \\
\hline $\begin{array}{l}1 / 2 \text { Cell } \\
\text { Mapping } \\
\text { Test / } \mu \mathrm{V}\end{array}$ & 82.48 & & -319.5 & \\
\hline $\begin{array}{l}\text { Chloride } \\
\text { Content }\end{array}$ & 0.189 & & 0.231 & \\
\hline
\end{tabular}

\section{$1 \%$}

\section{CONCLUSION}

The concrete reinforcement condition testing lab was set to determine the causes of corrosion of the reinforcement in concrete and haw each test carried out can assist in obtaining a clear image of the situation of the reinforcement in terms of problems, such as, corrosion. Moreover, the tests were carried out to find which of the two concrete specimens has more resistivity against corrosion and which one has more percentage of chloride content by rate of cement. It was found that the cover depth plays an important role in protecting the reinforcement in concrete. This means that the smaller the cover thickness, the more risk of corrosion and the opposite is true.

The main causes of corrosion are chloride and carbonation attacks with the presence of water and oxygen. The rate of corrosion is affected by different factors such as, humidity, temperature, presence of cracks and sea water. The corrosion can be prevented by adding corrosion inhibitors, surface treatments and protective coatings (Jackson, 1980).

The merits of concrete reinforcement condition testing are that they are direct, straightforward in testing, fast in operation and low in price. In opposition, the disadvantages are different from one test to the other. For instance, the disadvantage of cover depth is that it needs good calibration, while, the limitation of chloride content test is that it causes damage in the concrete.

The results for cover depth test showed that cube 1 has deeper cover thickness than cube 2. Furthermore, the reinforcement in both cube 1 and cube 2 were bent and not straight inside the concrete. Additionally, the results for concrete resistivity test showed that cube 1 had an average resistivity value of $3.925 \mathrm{k} \Omega$. This value was higher than that of cube 2 with $1.251 \mathrm{k} \Omega$. On the other hand, the results for $1 / 2$ - cell potential illustrated that cube 1 with an average of $82.48 \mu \mathrm{V}$ is also higher than cube 2 with $-319.5 \mu \mathrm{V}$. In addition, the chloride content test presented that cube 1 with $0.189 \%$ percentage of chloride by rate of cement has less chloride than cube 2 with $0.231 \%$, thus, cube 2 had chloride. Generally speaking, the results for all the tests were logical and illustrated that cube 1 had less potential for corrosion and more resistivity than cube 2 . According to concrete reinforcement condition testing results the following has been concluded:

- A smaller cover thickness means more risk of corrosion and less resistivity and potential. Thus, a deeper cover thickness gives a better concrete in terms of resistivity against corrosion.

- A positive resistivity value is better than a negative resistivity value. Thus, the more resistivity of the concrete indicates less risk of corrosion.

- If concrete resistivity value is less than $5 \mathrm{k} \Omega$ it is considered to be poor and with a very high rate of corrosion.

- The higher $1 / 2$ - cell potential value reveals a finer concrete with respect to more potential against corrosion.

- If $1 / 2$ - cell potential value is more than $-200 \mu \mathrm{V}$ then the percentage of corrosion is $5 \%$. 
- More percentage of chloride by rate of cements means more possibility of chloride attack and corrosion to take place.

There is a good relationship between all the four tests. The relation was that an increase in $1 / 2$ - cell potential with a decrease in chloride content means a good concrete in terms of more potential against corrosion. Generally speaking, the concrete resistivity and potential against corrosion is mainly affected by cover depth and chloride content. The results could have been improved by testing more concrete specimens and by carrying out other in-situ tests related to the determination of concrete reinforcement conditions.

\section{A C K N O W LE D GE M E N T}

I would like to thank my family for their moral support. Many thanks to Dr. Judith Halliday a senior lecturer at the University of Dundee and to all the staff of the Department of Civil Engineering in the University of Dundee for their technical support for providing the material and for making the concrete laboratory available for conducting this experimental study.

\section{R E F E R E N C E S}

ABDEL RAHIM, KHALID ABDEL NASER (2019),

Experimental study on the mix design and fresh properties of concrete, Volume 3, Issue 1, pp. 30-36, ISSN 2208-6404, Australian Journal of Science and Technology, Melbourne Scientific Publishers, Victoria, Australia. Available online at http://www.aujst.com/vol-3-1/04-AJST-70_REV.pdf

ABDEL RAHIM, KHALID ABDEL NASER (2019), Concrete Specification and Methods of Quality Testing, Volume 2, No.1, pp. 38-54, ISSN 2622-9374, Asian Institute of Research, Engineering and Technology Quarterly Reviews, Makassar, Indonesia. Available online

at https://www.asianinstituteofresearch.org/ETQRarchiv es/Concrete-Specification-and-Methods-of-QualityTesting-

AMERICAN SOCIETY FOR TESTING AND MATERIALS, (1999), American standard ASTM C867 - Measuring and interpreting reference electrode potentials or reinforced concrete, American Society for Testing and Materials (ASTM), USA.

AYLLON, T., KELLY, K., Effects of reinforcement on standardized test performance. J Appl Behav Anal. 1972 Winter;5(4):477-484.

BERGAN, A., MCMANIS, DL.,MELCHERT, PA., Effects of social and token reinforcement on WISC block design performance. Percept Mot Skills. 1971 Jun;32(3):871880.

BERTOLINI, L., (2004) Corrosion of steel in concrete : prevention, diagnosis, repair, Weinheim, Wiley-VCH.

BROOMFIELD, J. P. (2007) Corrosion of steel in concrete : understanding, investigation and repair, London; New York, Taylor \& Francis.

THE BRITISH STANDARDS INSTITUTION (BSI), (1988), BS 1881:Part 124: 1988. Methods for analysis of hardened concrete, The British Standards Institution (BSI), London.

THE BRITISH STANDARDS INSTITUTION (BSI), (1988), BS 1881: Part 204 - Testing concrete and recommendations on the use of electromagnetic cover meters (AMD 6201), The British Standards Institution (BSI), London.

THE BRITISH STANDARDS INSTITUTION (BSI), (1986), BS 1881: Part 201: 1986 - guide to the use of nondestructive methods of test for hardened concrete, The British Standards Institution (BSI), London.

BUILDING AND RESEARCH ESTABLISHMENT, (1986) Determination of the chloride and cement contents of hardened concrete, paper IP 21/86, Garston, Watford.

DAI, J. G., UEDA, T., "Chapter 14 Strength and deformability of concrete members wrapped with fiber-reinforced polymer composites with a large rupture strain."Innovative Materials and Techniques in Concrete Construction (Editor: Michael N. Fardis), 2011 Springer, 225-241.

DAWEI, W., ZHANG, T., UEDA, H., FURUUCHI, "Concrete cover separation failure of overlay-strengthened reinforcedconcrete beams."Construction and Building Materials, 26 (2012), pp. 735-745.

GIBSON, F. W., (1987) Corrosion, concrete, and chlorides : steel corrosion in concrete : causes and restraints, Detroit (P.O. Box 19150, Redford Station, Detroit 48219), American Concrete Institute.

HALLIDAY, J. (2010) Assessing Quality and Durability of Concrete. Lecture 3 Notes Concrete Assessment. University of Dundee, Dundee.

JACKSON, N. (1980) Civil engineering materials, London, Macmillan.

NEVILLE, A. M. (1996) Properties of concrete, New York, Wiley.

ZHANG, D.W., UEDA, T., FURUUCHI, H. "Concrete cover separation failure of overlay-strengthened reinforcedconcrete beams."Construction and Building Materials, 2012a,26, 735-745. 